\title{
Principal Leadership Style And Job Satisfaction Of High School Teachers
}

\author{
Erida Elmazi
}

\author{
P.h.D cand. Faculty of Economy, University of Tirana, Albania
}

\begin{abstract}
This paper deals with the issue of school leadership as one of the main priorities of education policy and focuses on the role, importance it has mainly on teacher's job satisfaction. It tends to highlight the influence of the school leaders' style in the pre-university education context. Two dimensions of leadership conceptualization are underlined in this study: the transformational and transactional leader. Teacher job satisfaction is often considered as an important aspect in their performance and productivity. In addition leadership style is considered one of the major influences affecting the job satisfaction of the teachers. The scope was to study the relationship and correlation between the style of the principals and job satisfaction of teachers. Various research techniques, primary and secondary data sources have been used to carry out this study, which are intertwined with one another. As a source of primary data were used two surveys, one for evaluating the principals' style of leadership and the other one for measuring job satisfaction of the teachers. The sample consisted in 5 teachers from 25 high schools in Albania and Kosovo. There is evidence from the findings that transformational leadership has significant relationship and it has beneficial effects on teacher job satisfaction. These leaders transform, inspire, and empower followers by creating changes in their goals, values, needs, beliefs and aspirations.
\end{abstract}

Keywords: job satisfaction, leadership styles, principal, teacher, transformational leadership, transactional leadership.

\section{Introduction}

When work is a pleasure, life is a joy (Gorky, 1970).

Researches in educational leadership have been the focus of scholars, considering the importance of the principal in the quality of the school. Several studies are conducted in this area and scholars have been investigating more narrow approaches in order to study specifically the dependent variables of educational leadership. Investigation is pursued in regard of relation with motivation, commitment, engagement, organizational communication, job satisfaction, etc.

In a globalized world the problems faced such as teacher turnover rates and training costs need a specific attention, clear designed strategies in order to increase their job satisfaction as a key factor in order to have a more stable environment for students and foster the organizational climate.

Teacher job satisfaction is very an important factor in the context of the school success and student achievement. In order that they create a positive classroom climate they need to be satisfied. Teachers cannot create and sustain the conditions for the productive development of students if those conditions do not exist for teachers (Bishop \& Mulford, 1999; Blase \& Blase, 2000; Louis, 1998; Sarason, 1990 cited by Leithwood \& Hallinger, 2002).

This research intended to study the impact of principal leadership styles on teachers' job satisfaction. The scope was to investigate how much satisfied are the teachers and to search how this level of satisfaction relates with their principals' leadership style. Can this level of satisfaction be attributed to principals' style? Based on 125 teachers perceptions, it was analyzed the style of their principals and beside this, it was investigated if the teachers were satisfied or not in their job. The first part of the study starts with a literature review on teacher job satisfaction, followed by transformational and transactional leadership styles. Scholars' findings within the literature conclude strong relationships among specific leadership styles and teachers job satisfaction. The research question of this study was: Which leadership style does impact and affect the teachers' job satisfaction in Albanian and Kosovo high schools? 


\section{Teacher Job Satisfaction}

The concept of job satisfaction has not a universal definition. There exist several definitions from several scholars. Job satisfaction is a positive or pleasant emotional state resulting from a person's appreciation of his/her own job or experience (Locke, 1976 cited in Demirtaş, 2010). It is defined as positive or negative evaluative judgments that people make regarding their work (Weiss, 1999) and their teaching role (Skaalvik \& Skaalvik, 2010). According to Amoroso (2002) teacher job satisfaction is refered as the degree to which a teacher feels secure, challenged, rewarded and successful at the current school in whic they work.

Accoring to Zigarreli (1996) teacher job satisfaction is predictor of effective schools. The importance of satisfaction can be tracked in psychological theories of hedonism. Hedonism has in its roots the idea that people are keen to ask for satisfaction and to avoid pain (Manxhari, 2010). It is natural that people seek to maximize pleasure and minimize the worrying situation or lack of comfort in their daily lives. The more pleasure people experience, the more motivated they have to be, and vice versa (Llaci, 2017). The accelerated rate of globalization and change has increased the challenges that institutions face. Achieving the organizational objectives has become difficult nowadays. The success and effectiveness cannot be reached without focusing and investing on human capital and human resources, who have to be motivated, evaluated and need to feel good at the work place. Teachers' job satisfaction is fundamental for reaching the school goals, thus ensuring satisfaction of the teachers is an important task of principals.

Teacher job satisfaction is important and also a predictor of teacher retention attrition (Green-Reese, Johnson, \& Campbell, 1992; Huberman, 1993; Sargent \& Hannum, 2005). Satisfaction is determined and influenced by several variables, such as internal and external school's factors, environment, reword policies, leadership styles, etc. Blegen (1993) identified 13 variables which he argued that were predictors of satisfaction. They were divided in two categories such as personal and organizational variables. According to him personal variables include age, education, years of experience and locus of control, whereas organizational variables include supervisor communication, commitment, stress, autonomy, recognition, routinization, peer communication, fairness and professionalism (cited: Güleryüz, Güney, Aydin, \& Asan, 2008 and Vermeir, et al., 2017).

\section{Leadership Styles and Influence on Job Satisfaction}

The manner in which a person leads an organization, department, team or individual is referred to as their leadership style (Krallis \& Souto, 2014). In contemporary literature there are discussed several leadership theories. Leadership styles such democtratic, autocratic, laissez faire, supportive, participatory, transactional, transformational, charismatics, instructional, servant, etc, have been elaborated. Special attention and interest has drawn on transactional and transformational leadership. Burns (1978) provided the conceptualized approach of these two leadership styles, as the opposite end of the leadership continuum. The origin of the concepts seems to date and have its root on Downtown (1973) work and later Bernard M Bass (1985) extended the work of Burns. According to Burns the main distinction between these leadership styles is based on the process by which leaders motivate followers or how leaders appeal to the followers' values and emotions (Nguni, Sleegers, \& Denessen, 2006). In fact this distinction is emphasized in all transformational approaches (Yukl, 1999).

Bass (1985) argues that transformational leadership has four components such as idealized influence, inspirational motivation, intellectual stimulation and individualized consideration. This leadership style articulates a vision of the future (Yammarino \& Bass, 1990), stimulates and inspires the followers and impacts their faith, values such as justice and integrity and guide how an organization should be effective and successful (Kuhnert \& Lewis, 1987). Transformational leaders increase the level of job satisfaction of employees by developing shared vision, motivating the followers (Voon, Lo, Ngui, \& Ayob, 2011). Teachers who work with principals, who share information with them, and involve them in management decisions are more satisfied (Bogler, 2001). Effective principals through convince may transform the institution. These kinds of principals motivate teachers in achieving extraordinary outcomes, they support and empower them.

Transactional leaders base their power on reword and punishment. According to Bass (1985) conceptualization of transactional leadership has three factors such as: management by active exception, management by passive exception and contingent reward (cited: Elmazi, 2018). Followers obey to the rules and guidelines determined by the leader and implement all the tasks. A successful implementation of the job is translated into a financial reward, 
otherwise delays and failure to comply will be translated into punishing actions. Transformational leaders differ from transactional leaders in that they do not merely recognize the needs of followers, but also attempt to elevate those needs from lower to higher levels of development and maturity (Nguni, Sleegers, \& Denessen, 2006).

Based on meta-analyses studies transformational and transactional leadership styles affect and predict lots of dependent variables on individual and institutional level. In the past and nowadays, scholars and researchers continuously have conducted several studies in order to investigate whether the leadership styles produce impacts on school outcomes and on teachers' job satisfaction. From a study conducted in China, with teacher respondents from 180 elementary schools, 172 secondary schools, and 187 high schools it was found that the principal's leadership style and teacher job satisfaction are significantly and positively related to each other: $\beta 2=0.17$, C.R. $=2.195, p<0.05$ (Hui, Jenatabadi, Ismail, \& Radzi, 2013). From several studies it has been demonstrated that there exists a significant positive relation between leadership style and employee job satisfaction (Rad \& Yarmohammadian, 2006; Bartolo \& Furlonger, 2000; Erkutlu, 2008; Hamidifar, 2009).

Over the years, the link between leadership styles and teacher job satisfaction has attracted the attention of many scholars. Several results of these findings are shown in the following table.

\begin{tabular}{|l|l|l|}
\hline & Transformational Leadership & Transactional Leadership \\
\hline (Koh, Steers, \& Terborg, 1995) & $\begin{array}{l}\text { From the investigation in 89 schools in Singapore, } \\
\text { it was found that transformational leadership style } \\
\text { had significant add-on effects to transactional } \\
\text { leadership in the prediction of organizational } \\
\text { commitment, organizational citizenship behavior, } \\
\text { and teacher satisfaction. }\end{array}$ & $\begin{array}{l}\text { Transactional style has a negative } \\
\text { impact on employees' job satisfaction. }\end{array}$ \\
\hline (Bogler, 2001) & $\begin{array}{l}\text { In his study developed in Israeli schools, with 745 } \\
\text { respondents, it was found that transformational } \\
\text { leadership style of principals affected teachers' } \\
\text { satisfaction both directly and indirectly through their } \\
\text { occupation perceptions. }\end{array}$ & \\
\hline (Barnett, McCormick, \& Conners, & $\begin{array}{l}\text { The study conducted in New South Wales in } \\
\text { secondary school showed that the transformational } \\
\text { leadership behavior (individual concern) was }\end{array}$ & \\
& $\begin{array}{l}\text { associated with the teacher outcomes - } \\
\text { satisfaction, extra effort and perception of leader } \\
\text { effectiveness. }\end{array}$ & \\
\hline (Griffith, 2004; Ejimofor, 2007) & $\begin{array}{l}\text { Transformational leadership style leads to a higher } \\
\text { level of performance and job satisfaction. }\end{array}$ & \\
\hline (Lee, 2005) & $\begin{array}{l}\text { From a study of 1,250 Taiwanese secondary } \\
\text { school, it was shown that the model of } \\
\text { transformational leadership has significant and } \\
\text { positive effects on job satisfaction and school } \\
\text { commitment teachers. }\end{array}$ & \\
\hline (Aydin, Sarier, \& Uysal, 2013) & $\begin{array}{l}\text { In Tanzanian primary school it was found that } \\
\text { transformational leadership dimensions have } \\
\text { strong effects on teachers' job satisfaction, } \\
\text { organizational commitment, and organizational } \\
\text { citizenship behavior. }\end{array}$ & \\
\hline (Nguni, Sleegers, \& Denessen, & $\begin{array}{l}\text { From a study conducted in 5 districts of Israeli, } \\
\text { transformational leadership was likely to affect } \\
\text { intra-school circumstances by promoting teachers' } \\
\text { satisfaction on the job. }\end{array}$ & \\
\hline 2006) & $\begin{array}{l}\text { research findings, conducted in Turkey, findings } \\
\text { showed that transformational leadership style } \\
\text { affected positively job satisfaction and } \\
\text { organizational commitment of teachers. }\end{array}$ & \\
\hline
\end{tabular}




\section{Methodology}

In this study, we have tried to identify whether, in the Albanian and Kosovo context, principal style of leadership influences the teacher satisfaction. The methodology followed in this paper has a quantitative approach. Two quantitative questionnaires using Likert-type scales were administered. Questionnaires were used to identify the principal style of leadership as perceived by teachers, and the teacher satisfaction. For identifying the leadership style of principal, the Multifactor Leadership Questionnaire (MLQ) Form 5X was used in order to measure seven factors, such as: Idealized influence, Inspirational motivation, Intellectual stimulation, Individual consideration, Contingent reward, Management-byexception, Laissez-faire. For capturing of teacher satisfaction, a questionnaire was borrowed from the Ciampini-Boccardo Institute of Higher Education with 6 items was used. The questionnaire was distributed physically among the teachers of 25 primary schools in Albania. There were a total of 125 responses from 200 distributed questionnaires.

\section{Analysis of results}

The study involved 125 primary school teachers, where $86.4 \%$ were woman and $13.6 \%$ were man, all with a high level of education. Respondents (teachers) were asked about the perception they have on the principal style of leadership, and their job satisfaction. Responses were measured with a Likert scale of 1-5.

For data analysis the statistical program SPSS, was used. We have measured the impact that principal leadership style has on teacher satisfaction through simple regression analysis. Specifically we have tested the impact that the transactional leadership of principal and transformational leadership of principal, plays on teacher satisfaction.

Coefficients $^{a}$

\begin{tabular}{|c|c|c|c|c|c|c|}
\hline \multirow{2}{*}{\multicolumn{2}{|c|}{ Model }} & \multicolumn{2}{|c|}{ Unstandardized Coefficients } & \multirow{2}{*}{\begin{tabular}{|l|}
$\begin{array}{l}\text { Standardized } \\
\text { Coefficients }\end{array}$ \\
Beta
\end{tabular}} & \multirow[b]{2}{*}{$T$} & \multirow[b]{2}{*}{ Sig. } \\
\hline & & $B$ & Std. Error & & & \\
\hline \multirow[t]{2}{*}{1} & (Constant) & $-4.127 \mathrm{E}-16$ & .090 & & .000 & 1.000 \\
\hline & Satisfaction & -.071 & .090 & -.071 & -.786 & .043 \\
\hline
\end{tabular}

a. Dependent Variable: Transformational Leadership

Coefficientsa

\begin{tabular}{|c|c|c|c|c|c|c|}
\hline \multirow{2}{*}{\multicolumn{2}{|c|}{ Model }} & \multicolumn{2}{|c|}{ Unstandardized Coefficients } & \multirow{2}{*}{\begin{tabular}{|l|}
$\begin{array}{l}\text { Standardized } \\
\text { Coefficients }\end{array}$ \\
Beta
\end{tabular}} & \multirow[b]{2}{*}{$T$} & \multirow[b]{2}{*}{ Sig. } \\
\hline & & $B$ & Std. Error & & & \\
\hline & (Constant) & $-4.936 \mathrm{E}-17$ & .090 & & .000 & 1.000 \\
\hline & Satisfaction & -.003 & .090 & -.003 & -.029 & .097 \\
\hline
\end{tabular}

a. Dependent Variable: Transactional Leadership

Regression analysis shows that transactional leadership does not affect teacher satisfaction, for a confidence level of $95 \%$, while the transformational style of leadership, for the same confidence level, positively impacts the teacher satisfaction.

Correlative analysis has been used to test the strength of this relationship (teacher satisfaction and transformational leadership style). The results show that transformational leadership style of principal has a strong, positive effect on teacher satisfaction. 
Correlations

\begin{tabular}{|ll|l|l|l|}
\hline & & $\begin{array}{l}\text { Transformational } \\
\text { Leadership }\end{array}$ & Satisfaction & $\begin{array}{l}\text { Transactional } \\
\text { Leadership }\end{array}$ \\
\hline Transformational Leadership & Pearson Correlation & 1 & .071 & -.066 \\
& Sig. (2-tailed) & & .043 & .462 \\
& $\mathrm{~N}$ & 125 & 125 & 125 \\
\hline Satisfaction & Pearson Correlation & .071 & 1 & -.003 \\
& Sig. (2-tailed) & .043 & 125 & 125 \\
\hline N & 125 & -.003 & 1 \\
\hline Transactional Leadership & Pearson Correlation & -.066 & .097 & 125 \\
\hline
\end{tabular}

\section{CONCLUSIONS}

A common conclusions about transformational leadership style emerge from the literature review: it is an important management and leading style, which promotes work performance and employee satisfaction, as it has already been proven by several relevant research studies in the past (Keller, 1992; Howell and Avolio, 1993; Lowe, 1996; Pawar and Eastman, 1997; Thite, 2000; Nielsen 2009; Paulsen, 2009; Eisenbeis and Boerner, 2010; Liu, 2011; Ahmad, 2013 cited: Krallis \& Souto, 2014).

This study sought to examine the relationship between principal leadership and teacher satisfaction in the Albanian and Kosovo context. According to the results of the study, transformational leadership positively effects teacher satisfaction. Furthermore, this relationship appears to be strong. Job satisfaction is an important predictor of effective schools thus principals should pay a great atention to their behaviors and consider implementing effective strategies in order to increase the teachers' job satisfaction. Moreover a great attention should be paid by gonverment and their educational reforms who should consider to implement special actions.

\section{BIBLIOGRAPHY}

[6] Amoroso, P. F. (2002). The Impact Of Principals' Transformational Leadership Behaviors On Teacher Commitment And Teacher Job Satisfaction. Seton Hall University Dissertations and Theses .

[7] Aydin, A., Sarier, Y., \& Uysal, S. (2013). The Effect of School Principals' Leadership Styles on Teachers' Organizational Commitment and Job Satisfaction. Educational Sciences: Theory \& Practice , 806-811.

[8] Barnett, K., McCormick, J., \& Conners, R. (2001). Transformational leadership: panacea, placebo, or problem? Journal of Educational Administration , 24-46.

[9] Bartolo, K., \& Furlonger, B. (2000). Leadership and job satisfaction among aviation fire fighters in Australia. Journal of Managerial Psychology, 87-93.

[10] Bishop, P., \& Mulford, W. (1999). When will they ever learn? Another failure of centrally-imposed change. School Leadership and Management, 179-187.

[11] Blase, J., \& Blase, J. (2000). Implementation of shared governance for instructional improvement: Principals' perspectives. Journal of Educational Administration , 476-500.

[12] Blegen, M. A. (1993). Nurses' job satisfaction: A meta-analysis of related variables. Nursing Research , 36-41.

[13] Bogler, R. (2001). The Influence of Leadership Style on Teacher Job Satisfaction. Education Administration Quarterly , 662-683.

[14] Burns, J. M. (1978). Leadership. New York: Harper ve Row.

[15] Ejimofor, F. O. (2007). Principals' Transformational Leadership Skills and Their Teachers' Job Satisfaction in Nigeria. Cleveland State University, USA. : Doctoral dissertation.

[16] Elmazi, E. (2018). The influence of leadership styles on employee's engagement: a case study from Albanian bank sector. Journal of Knowledge Management, Economics and Information Technology . 
[17] Erkutlu, H. (2008). The impact of transformational leadership on organizational and leadership effectiveness: The Turkish case. Journal of management development , 708-726.

[18] Gorky, M. (1970). Key Concept. Groupwork, 107-132.

[19] Green-Reese, S., Johnson, D., \& Campbell, W. (1992). Teacher job satisfaction and teacher job stress: School size, age and teaching experience. Educations , 247-252.

[20] Griffith, J. (2004). Relation of principal transformational leadership to school staff job satisfaction, staff turnover, and school performance. Journal of Educational Administration , 333-356.

[21] Güleryüz, G., Güney, S., Aydin, E. M., \& Asan, Ö. (2008). The mediating effect of job satisfaction between emotional intelligence and organisational commitment of nurses: A questionnaire survey. International Journal of Nursing Studies , 1625-1635.

[22] Hamidifar, F. (2009). A study of the relationship between leadership styles and employee job satisfaction at Islamic Azad University branches in Tehran, Iran. AU-GSB- e-Journal , 1-13.

[23] Huberman, M. (1993). The lives of teachers. London: Cassell.

[24] Hui, H., Jenatabadi, H. S., Ismail, N. A., \& Radzi, C. W. (2013). Principal's Leadership Style and Teacher Job Satisfaction: A Case Study in China. Interdisciplinary Journal of Contemporary Research in Business , 175-184.

[25] Koh, W. L., Steers, R. M., \& Terborg, J. R. (1995). The effects of transformational leadership on teacher attitudes and student performance in Singapore. Journal of organizational behavior , 319 - 333.

[26] Krallis, A., \& Souto, C. (2014). Leadership Style, National Culture and Employee Satisfaction: Empirical Evidence from European R\&D Companies. BLEKINGE INSTITUTE OF TECHNOLOGY.

[27] Kuhnert, K., \& Lewis, P. (1987). Transactional and transformational leadership: A constructive developmental analysis. Academy of Management Review , 648-657 .

[28] Lee, Y. Y. (2005). Teachers' perceptions of principals' transformational leadership and teachers' job satisfaction and school commitment. ETD Collection for Fordham University .

[29] Leithwood, K., \& Hallinger, P. (2002). Second International Handbook of Educational Leadership and Administration. Në H. Silins, \& B. Mulford, Leadership and school results (fv. 561-612). Dordrecht, The Netherlands: Kluwer Academic Publishers.

[30] Llaci, S. (2017). Manaxhimi. Tiranë: albPAPER.

[31] Locke, E. A. (1976). The nature and causes of job satisfaction. In M. D. Dunette, Handbook of industrial and organizational psychology (pp. 1069-1073). Chicago: RandMcNally, cited by Demirtaş, Zülfü (2010), Teachers' job satisfaction levels, Procedia Social and Behavioral Sciences, 1069-1073.

[32] Louis, K. S. (1998). Effects of teacher quality of work life in secondary schools on commitment and sense of efficacy. School Effectiveness and School Improvement, 1-27.

[33] Manxhari, M. (2010). Sjellja në Organizatë. Tiranë: Onufri.

[34] Nguni, S., Sleegers, P., \& Denessen, E. (2006). Transformational and transactional leadership effects on teachers' job satisfaction, organizational commitment, and organizational citizenship behavior in primary schools: The Tanzanian case. S. School effectiveness and school improvement , 145-177.

[35] Nir, A. E., \& Kranot, N. (2006). School Principal's Leadership Style and Teachers' Self-Efficacy. Planning and Changing , 205-218.

[36] Rad, A. M., \& Yarmohammadian, M. H. (2006 ). A study of relationship between managers' leadership style and employees' job satisfaction. Leadership in Health Services , 11-28.

[37] Sarason, S. (1990). The predictable failure of educational reform. San Francisco, CA: Jossey-Bass.

[38] Sargent, T., \& Hannum, E. ( 2005). Keeping teachers happy: job satisfaction among primary school teachers in rural northwest China. Comparative Education Review , 173-204.

[39] Skaalvik, E., \& Skaalvik, S. (2010). Teacher self-efficacy and teacher burnout: A study of relations. eaching and Teacher Education, 1059-1069.

[40] Vermeir, P., Degroote, S., Vandijck, D., Mariman, A., Deveugele, M., Renaat Peleman, V. R., et al. (2017). Job Satisfaction in Relation to Communication in Health Care Among Nurses: A Narrative Review and Practical Recommendations. SAGE Open .

[41] Voon, M. L., Lo, M. C., Ngui, K. S., \& Ayob, N. (2011). The influence of leadership styles on employees' job satisfaction in public sector organizations in Malaysia. International Journal of Business, Management and Social Sciences , 24-32. 
[42] Weiss, E. (1999). Perceived workplace conditions and first-year teachers' morale, career choice commitment, and planned retention: A secondary analysis. Teaching and Teacher Education , 861-879.

[43] Yammarino, F., \& Bass, B. (1990). Long-term forecasting and of transformational leadership and its effects among naval officers: Some preliminary findings. In K. Clark, \& M. Clark, Measures of leadership (pp. 151-169). West Orange, NY: Leadership Library of America.

[44] Yukl, G. (1999). An evaluation of conceptual weakness in transformational and charismatic leadership theories. The Leadership Quarterly , 285 - 305.

[45] Zigarreli, M. A. ( 1996). An empirical test of conclusions from effective schools research. The Journal of Educational Research, 103-109. 